\title{
Investigation of Enterococcus faecalis population in patients with polyp and colorectal cancer in comparison of healthy individuals
}

\author{
Maryam GERAVAND ${ }^{1}$, Parviz FALLAH ${ }^{2}$, Mojtaba Hedayat YAGHOOBI ${ }^{3}$, Fatemeh SOLEIMANIFAR ${ }^{4}$, \\ Malihe FARID ${ }^{5,6}$, Nazi ZINATIZADEH ${ }^{1}$ and Somayeh YASLIANIFARD ${ }^{4,7}$
}

Received 14/12/2018 Accepted 5/6/2019

\begin{abstract}
Background - Colorectal cancer is one of the most commonly diagnosed cancers around the world. One of the factors involved in the development of colorectal cancer is the changes in the normal flora of the intestine. Objective - In this study, the mean copy number of Enterococcus faecalis in people with polyps and people with colorectal cancer has been evaluated in comparison with healthy controls. Methods - In this study, 25 patients with colorectal cancer and 28 patients with intestinal polyps were selected and stool specimens were taken. In addition, 24 healthy individuals were selected as control group. Extraction of bacterial DNA from the stool sample were performed. The molecular methods of PCR for confirmation of standard strain and absolute Real Time PCR (qRT-PCR) method were used to evaluate the number of Enterococcus faecalis in the studied groups. Results - The results of this study indicate that the mean copy number of Enterococcus faecalis in patients with colorectal cancer was $11.2 \times 10^{9}$ per gram of stool, and in patients with polyps was $9.4 \times 10^{8}$ per gram of stool. In healthy people, this number was $9 \times 10^{8}$ per gram of stool. There was a significant difference between the implicit copy numbers in the three groups. $(P<0.05)$. Conclusion - Enterococcus faecalis in faecal flora of people with colorectal cancer was significantly higher than those with polyps and healthy people. This could potentially signify the ability of this bacterium to induce colorectal cancer. More studies are needed to prove this theory.
\end{abstract}

HEADINGS - Colorectal neoplasms. Intestinal polyps. Enterococcus faecalis. Real-time polymerase chain reaction.

\section{INTRODUCTION}

Colorectal cancer is one of the most common cancers around the world ${ }^{(1)}$. This complication after lung and breast cancer is ranked third among women, and is the most prevalent in men after lung and prostate cancer. The risk of developing this cancer starts at age 41 , and its prevalence is directly related to age ${ }^{(2)}$.

Geographic variation and various time intervals in the incidence of colorectal cancer suggest that environmental factors and lifestyle are among the major factors in the development of this disease. Environmental factors have a more important role in the development of colorectal cancer than genetic factors ${ }^{(3)}$.

The polyps of the intestine are masses created in the inner lining of the colon. Adenomatous polyps are potentially capable of becoming cancerous ${ }^{(4)}$. The intestinal microbial population is known as "intestinal microbiota" and consists of more than 1,000 different bacterial species. Microbiota analysis allows the analysis of environmental factors and interaction with the host. This complex ecosystem helps maturation of the immune system and it prevents direct colonization of the pathogens in the intestine. This ecosystem also can metabolize procarcinogens and environmental cancers ${ }^{(5)}$.

A total of 80 to 90 percent of intestinal bacteria are located in two branches of Bacteroides and Firmicutes. In addition, actinobac- teria and proteobacteria are from other bacteria in the intestines ${ }^{(6)}$. Germs play an important role in carcinogenic infections, which account for $20 \%$ of cancers with a predominance of colorectal cancer $^{(7)}$. For example, colibactin is a secondary metabolite of $E$. coli that can interfere with the cell cycle. This disorder may triggers the development and extension of colorectal cancer ${ }^{(8)}$.

Enterococcus faecalis has been introduced as a causative agent for oxidative stress ${ }^{(9)}$. Oxidative stress results from an imbalance between the production of active oxygen radicals and the body's antioxidant system. Oxidative stress plays an important role in the development of cancer ${ }^{(10)}$. The most active oxygen species are superoxide, hydrogen peroxide, and hydroxyl radicals. These free radicals have an effect on the cell cycle in cancer progression ${ }^{(11)}$.

Enterococcus faecalis damage the colon epithelial DNA by producing reactive oxygen radicals. Reactive oxygen radicals play a role in the formation of adenomatous polyps and colorectal cancer ${ }^{(12)}$.

Some studies on fecal microbial flora and gastrointestinal cancers, especially colorectal cancer, have been reported, indicating a difference in fecal microbial flora among people with colorectal cancer and healthy individuals ${ }^{(13)}$. Considering this issue, the purpose of this study is to compare the mean copy of Enterococcus faecalis in people with polyps and colorectal cancer in comparison with healthy individuals in order to investigate the association of this bacterium with polyp and colorectal cancer. 


\section{METHODS}

\section{Sampling}

In this study, 25 patients with colorectal cancer and 28 patients with polyps and 24 healthy subjects were evaluated. The criteria for entering this study were not to use antibiotics in the previous month, lack of probiotics consumption, no familial history of intestinal polyps and no history of inflammatory bowel disease. The subjects were selected on the basis of colonoscopy and positive pathology for polyp and colorectal cancer and negative pathology for healthy subjects. The patients' information was collected in a questionnaire and stool specimens were placed on ice and transferred to the laboratory.

\section{Preparation of standard strain}

Standard strain of Enterococcus faecalis (ATCC: 29212) was prepared from the Iranian Biological Resource Center (IBRC). This strain was cultured in Blood Agar (BA) and Tryptic soy broth (TSB) media. After bacterial growth for 48 hours, suspensions from bacterial colonies were prepared for DNA extraction.

\section{Genomic DNA extraction}

Using Qia amp DNA stool mini kit (Qiagen) and the tissue genomic DNA extraction mini kit (Favorgen Biotech Corp), genomic DNA of fecal specimens and standard strains were extracted. DNA concentrations were determined with the Nano Drop 2000 (Thermo. Scientific) and stored at $-20^{\circ} \mathrm{C}$ prior to amplification steps.

\section{Polymerase chain reaction (PCR)}

Forward and reverse primers for Enterococcus faecalis was 5' - ATCAAGTACAGTTAGTCTTTATTAG -3'; 5' - ACGATTCAAAGCTAACTGAATCAGT -3', respectively. The final volume of the PCR reaction was $25 \mu \mathrm{L}$ containing $2.5 \mu \mathrm{L}$ reaction buffer, $2 \mu \mathrm{L}$ of template, $1 \mu \mathrm{L}$ (each) primer, $1 \mu \mathrm{L}$ DNTP (mix), $0.5 \mu \mathrm{L}$ Taq polymerase, $2 \mu \mathrm{L}$ DNA- template, $1 \mu \mathrm{L} \mathrm{Mgcl} 2$. PCR was performed with an initial denaturation step of $94^{\circ} \mathrm{C}$ for $5 \mathrm{~min}$, followed by 30 cycles of $94^{\circ} \mathrm{C}$ for $1 \mathrm{~min}$, and $55^{\circ} \mathrm{C}$ for $30 \mathrm{~s} .5$ $\mu \mathrm{L}$ of the PCR was subjected to electrophoresis on a $2 \%$ agarose gel containing Gelred. Finally, the DNA bands were visualized by UV illumination to confirm the generation of 113-bp amplicon.

\section{Real-time quantification PCR}

Quantitative RT-PCRs were performed in a reaction volume of $20 \mu \mathrm{L}$ containing $10 \mu \mathrm{L}$ SYBR Green PCR Master Mix, $1 \mu \mathrm{L}$ each of the forward and reverse primers, $2 \mu \mathrm{L}$ rox and $2 \mu \mathrm{L}$ of DNA extracted from the fecal samples. The amount of DNA was determined in duplicate, and the mean values were determined. Amplification and detection of DNA were performed with the LightCycler\&reg; 96 Real-Time PCR System - Roche Life Science. The reaction conditions were $95^{\circ} \mathrm{C}$ for $2 \mathrm{~min}$ and $95^{\circ} \mathrm{C}$ for $5 \mathrm{~s}$, followed by 40 cycles of $95^{\circ} \mathrm{C}$ for $15 \mathrm{~s}$ and $55^{\circ} \mathrm{C}$ for $10 \mathrm{~s}$. Data analysis was done using sequence detection software lightcycler 96. As shown in FIGURE 1 purified genomic DNA in the range $1 \mathrm{ng}$ of Enterococcus faecalis was used as the standard for determining the amount of lactobacillus acidophilus and lactobacillus plantarum DNA by real-time PCR. Absolute quantification was (a)

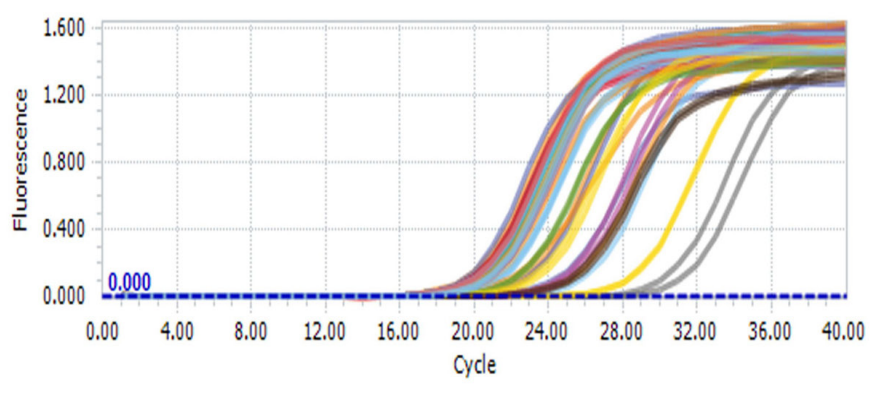

(b)

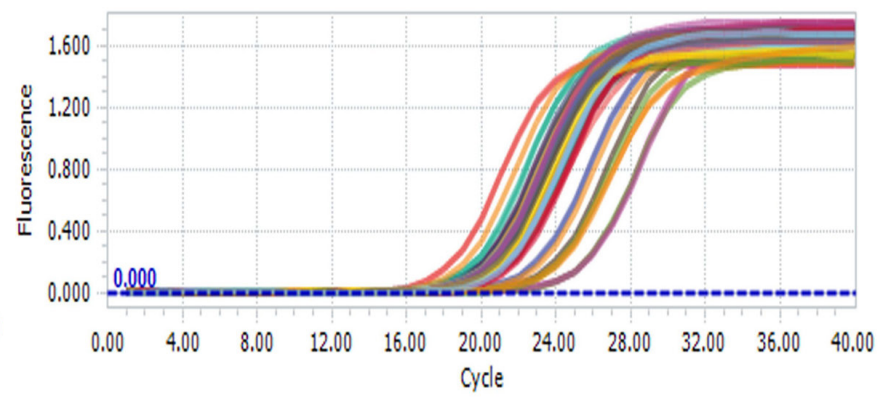

(c)

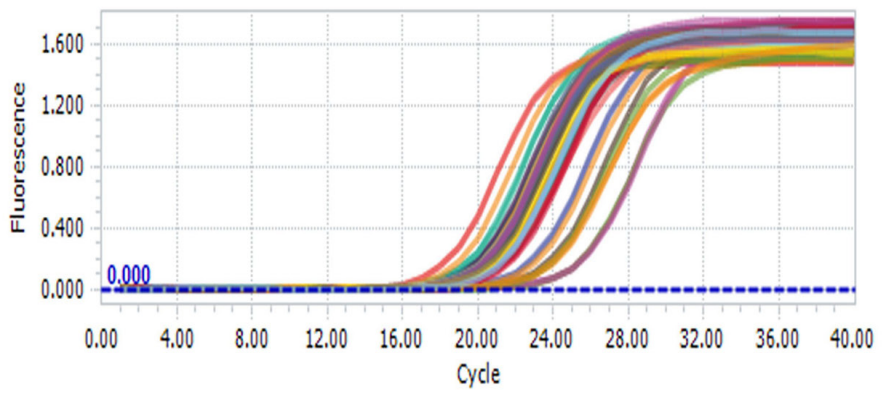

FIGURE 1. Real-time quantification PCR graphs of total bacterial loada. a) Enterococcus faecalis - healthy control, b) Enterococcus faecalis - polyps, c) Enterococcus faecalis - colorectal cancer. 
used to determine the copy of the bacterial expression per gram of feces using LightCycler ${ }^{\circledR}$ 96. In the sample editor section, at least three concentrations were selected from the standard strains, and the copy number of the bacteria per gram of feces were determined in each sample based on the standard curves.

\section{Statistical analysis}

Obtained Real time PCR results, and the results of the completed questionnaires were analyzed. Descriptive data were analyzed using the Statistical Package for the Social Sciences 14 (SPSS 14). For statistical analysis, Chi-Square, Mann-Whitney Test, and Kruskal-Wallis Test tests were applied for data analysis. $P$-values of less than $<0.05$ was considered significant.

\section{RESULTS}

\section{Sampling and demographic analysis}

The mean age of patients with colorectal cancer was $54 \pm 11$, the mean age of patients with polyp was $54 \pm 9.4$ and mean age of healthy subjects was $50 \pm 10.2$. There was no significant difference between age group of patients with polyp, colorectal cancer and healthy individuals $(P>0.05)$. There was no significant difference in smoking in all colorectal cancer, polyp and healthy groups $(P=0.6)$. The findings of this study showed that in people with colorectal cancer $16(21.6 \%)$, in people with polyp, 9 and 11 healthy subjects had Fat-rich diet. Data analysis showed that there was no significant difference between the three polyp, colorectal cancer and healthy groups regarding the consumption of high-fat foods $(P=0.15)$. The findings showed that 14 patients with colorectal cancer, 14 patients with polyps and 7 healthy individuals had a blood type of $\mathrm{O}$. The results show that there is a significant difference between people with O-group with polyp and colorectal cancer compared to healthy subjects. $(P<0.00001)($ TABLE 1$)$.

TABLE 1. Demographic data recorded for each study participant included age, blood group, fat food and smoking.

\begin{tabular}{lcccc}
\hline Variables & $\begin{array}{c}\text { Healthy } \\
\text { N }(\%)\end{array}$ & $\begin{array}{c}\text { Polyp } \\
\text { N }(\%)\end{array}$ & $\begin{array}{c}\text { Cancer } \\
\text { N }(\%)\end{array}$ & $P$-value \\
\hline Smoking & $5(17.9)$ & $9(14.3)$ & $8(28.6)$ & 0.68 \\
Age & $50 \pm 10.2$ & $54 \pm 9.4$ & $54 \pm 11$ & 0.06 \\
A blood group & $5(17.9)$ & $6(21.4)$ & $6(21.4)$ & 0.12 \\
B blood group & $10(35.7)$ & $4(14.3)$ & $4(14.3)$ & 0.14 \\
AB blood group & $6(21.4)$ & $4(14.3)$ & $4(14.3)$ & 0.07 \\
O blood group & $7(25)$ & $14(50)$ & $14(50)$ & 0.00 \\
Fat-rich diet & $11(17.9)$ & $9(14.6)$ & $16(21.6)$ & 0.15 \\
\hline
\end{tabular}

\section{Real-time quantification PCR of total Enterococcus faecalis load}

The mean copy number of Enterococcus faecalis was calculated in three groups (FIGURE 1). There was a significant difference in the number of copies in three groups $(P<0.05)$. In this study, the mean copy number of Enterococcus faecalis in patients with colorectal cancer was higher than the mean copy number of this bacterium in people with polyps and healthy individuals. Also the mean copy number of Enterococcus faecalis in patients with polyps was higher than that of healthy control (TABLE 2).
TABLE 2. Average copy number of Enterococcus faecalis in each groups.

\begin{tabular}{lcccc}
\hline $\begin{array}{l}\text { Study } \\
\text { groups }\end{array}$ & $\begin{array}{c}\text { Average (copy } \\
\text { number per gram } \\
\text { feces } \pm \text { SD) }\end{array}$ & $\begin{array}{c}\text { Total } \\
\boldsymbol{P} \text {-value }\end{array}$ & $\boldsymbol{P}$-value \\
\hline Healthy & $9.24 \times 10^{8} \pm 3.81 \times 10^{6}$ & & $\begin{array}{c}\text { Healthy/ } \\
\text { Polyp }\end{array}$ & 0.07 \\
Polyp & $9.44 \times 10^{8} \pm 2.11 \times 10^{6}$ & 0.00 & $\begin{array}{c}\text { Polyp/Cancer } \\
\text { Healthy/ } \\
\text { Cancer }\end{array}$ & 0.002 \\
Cancer & $1.22 \times 10^{9} 1.25 \times 10^{8}$ & & 0.001 \\
\hline
\end{tabular}

\section{DISCUSSION}

In this study, the possible role of Enterococcus faecalis in the development of polyp and colorectal cancer is surveyed. To this end, for the first time in Iran, the qPCR method was used for absolute quantification of the number of Enterococcus faecalis in fecal specimens of people with polyps or colorectal cancer.

The previous studies proposed that the microbiota can influence apoptosis and inflammation in the subjects with some cancers. Gut is an important area for detecting microorganisms, so it is usually used for investigation of relationship between pathogenic agents and colorectal cancer ${ }^{(14)}$. The gut microorganisms can interfere in the functions of metabolism, mucosal barrier, and angiogenesis through alteration in the expression of their host genes. Enterococcus faecalis belongs to Firmicutes family, can be a pathogenic agent and damage colonic epithelial cell $\mathrm{DNA}^{(15)}$.

The role of some bacteria in causing chronic infections or production of toxic agents which affected the cell growth has been reported $^{(16,17)}$. It can lead to initiate the tumorigenesis. Also, some bacterial infections can escape from the immune system or incite immune responses through the cytokines which are released by inflammatory cells including interleukin-8 (IL-8), reactive oxygen species (ROS), and nitric oxide (NO). The production of these substances accompany with accompany with other factors like smoking can considerably develop carcinogenesis ${ }^{(18-20)}$.

The results of this study showed that the mean copy number of Enterococcus faecalis in the fecal specimens of the subjects with colorectal cancer was higher than those of in the patient with polyps and both of them showed the higher copy number of this bacterium than healthy group. Also, there was a significant difference between the numbers of Enterococcus faecalis in the feces of the subjects with colorectal cancer compared to those with polyps. There was no significant difference between the numbers of Enterococcus faecalis in the fecal specimens of people with polyps and healthy subjects $(P=0.07)$.

Other studies showed that Enterococcus faecalis induces changes in DNA of colon epithelial cells and increases invasive colitis, dysplasia and adenocarcinoma in mice without IL10 ${ }^{(21)}$. Studies in the animal model indicate that changes in the immune system and inflammatory responses can contribute to the promotion of cancers $^{(22)}$. Intestinal microbiota can play several roles in the production of NOS, activating macrophages, and inflammatory responses that damage the colon epithelial cell DNA ${ }^{(23)}$. In addition, Enterococcus faecalis in the gastrointestinal tract produces extracellular superoxide $(\mathrm{O} 2)$ due to its metabolic activity, which can cause intestinal polyps or colorectal cancers ${ }^{(11,12,24,25)}$, so Enterococcus faecalis can play an important role in gastrointestinal cancer.

The results of this study showed that there is a significant difference between people with O-group with polyp and colorectal cancer compared to healthy subjects. Therefore, it seems that individuals 
who have an O-group are more prone to polyps and colorectal cancer. The results of this study also indicate that most people with colorectal cancer are between 65-65 years old. This result is in consistent with previous studies ${ }^{(2)}$. In this study, possible confounding factors such as cigarette, fat diet or age were evaluated. There was no significant difference in the age of subjects in the studied groups. Several studies have found that smoking or the use of a fatty diet are relevant to the types of cancer, but in this survey there was no significant relationship between smoking and high fat diet in the development of polyp or colorectal cancer.

Evidence from this study suggests the effectiveness of Enterococcus faecalis in inducing colorectal cancer. Since cancer is a multifactorial disease, any generalization of effective factors in the induction of cancer should be done with caution. In a study recently conducted by our research team to determine the role of Lactobacillus in inducing or preventing the spread of adenoma or colorectal cancer ${ }^{(2)}$, lactobacilli may could have a preventive role in the induction or spread of malignancy. The results of this study and our previous study ${ }^{(26)}$, indicate the dual role of bacteria in preventing or inducing malignancy. These results could be an introduction to more extensive studies on the microbiome of colorectal cancer patients compared to healthy people to provide more clarity and broader scope to determine the role of bacteria in the health and illness of individuals.

\section{CONCLUSION}

In this study, the presence of Enterococcus faecalis was evaluated in people with polyps and colorectal cancer in comparison of healthy individuals. It is worth noting that in this study, none of the subjects were biologically treated and there was no probiotic in their diet. The results of this study show that there is a significant difference between the population of enterococcus faecalis with polyps and colorectal cancer compared to healthy individuals. In this study, for the first time, there was a direct correlation between the occurrence of polyps and colorectal cancer with the $\mathrm{O}$ blood group, which would require more studies to prove this hypothesis in the future. The results of this study indicate that intestinal microbial flora can potentially contribute to malignancy. Therefore, monitoring and controlling the Intestinal microbial population especially Enterococcus faecalis may be a way to prevent colorectal cancer, especially in people with a history of polyps and colorectal cancer in their family.

\section{ACKNOWLEDGEMENT}

We thank the Staff of Bahonar Hospital in Alborz Province for providing the fecal samples that were used in this study.

\section{Authors' contribution}

Geravand M: laboratory expriments, data analysis and writing of the manuscript. Fallah P: laboratory expriments and data analysis. Yaghoobi MH: study design and clinical diagnosis. Soleimanifar F: laboratory expriments. Farid M: data analysis. Zinatizadeh N: laboratory expriments. Yaslianifard S: study design, laboratory expriments, data analysis and writing of the manuscript.

\section{Orcid}

Maryam Geravand. Orcid: 0000-0002-5426-2132.

Parviz Fallah. Orcid: 0000-0002-1900-9959.

Mojtaba Hedayat Yaghoobi. Orcid: 0000-0003-4243-5654.

Fatemeh Soleimanifar. Orcid: 0000-0002-8096-9924.

Malihe Farid. Orcid: 0000-0003-4614-7588.

Nazi Zinatizadeh. Orcid: 0000-0002-3852-7778.

Somayeh Yaslianifard. Orcid: 0000-0001-8423-0652.

Geravand M, Fallah P, Yaghoobi MH, Soleimanifar F, Farid M, Zinatizadeh N, Yaslianifard S. Investigação da população de Enterococcus faecalis em pacientes com pólipo e câncer colorretal em comparação a indivíduos saudáveis. Arq Gastroenterol. 2019;56(2):141-5.

RESUMO - Contexto - O câncer colorretal é um dos cânceres mais comumente diagnosticados em todo o mundo. Um dos fatores envolvidos no desenvolvimento do câncer colorretal é a mudança na flora normal do intestino. Objetivo - O número médio de cópias de Enterococcus faecalis em pessoas com pólipos e pessoas com câncer colorretal foram avaliados em comparação com controles saudáveis. Métodos - Neste estudo, 25 pacientes com câncer colorretal e 28 pacientes com pólipos intestinais foram selecionados e amostras de fezes foram adquiridas. Além disso, 24 indivíduos saudáveis foram selecionados como grupo controle. A extração do DNA bacteriano da amostra coletada foi executada. Os métodos moleculares de PCR para confirmação da cepa padrão e o método absoluto de PCR em tempo real (qRT-PCR) foram utilizados para avaliar o número de Enterococcus faecalis nos grupos estudados. Resultados - Os resultados deste estudo indicam que o número médio de cópias de Enterococcus faecalis em pacientes com câncer colorretal foi de $11,2 \times 10^{9}$ por grama de fezes, e em pacientes com pólipos foi de 9,4x10 por grama de fezes. Em pessoas saudáveis, este número foi de $9 \times 10^{8}$ por grama de fezes. Houve diferença significativa entre os números de cópia implícita nos três grupos. $(P<0,05)$. Conclusão - Enterococcus faecalis na flora fecal de pessoas com câncer colorretal foi significativamente maior do que aqueles com pólipos e pessoas saudáveis. Isto poderia potencialmente significar a capacidade desta bactéria para induzir o câncer colorretal. Mais estudos são necessários para provar esta teoria.

DESCRITORES - Neoplasias colorretais. Pólipos intestinais. Enterococcus faecalis. Reação em cadeia da polimerase em tempo real. 


\section{REFERENCES}

1. Siegel R, Desantis C, Jemal A. Colorectal cancer statistics, 2014. CA Cancer J Clin. 2014;64:104-17.

2. Ansari R, Mahdavinia M, Sadjadi A, Nouraie M, Kamangar F, Bishehsari F, et al. Incidence and age distribution of colorectal cancer in Iran: results of a population-based cancer registry. Cancer Lett. 2006;240:143-7.

3. Wakai K, Hirose K, Matsuo K, Ito H, Kuriki K, Suzuki T, et al. Dietary risk factors for colon and rectal cancers: a comparative case-control study. J Epidemiol. 2006;16:125-35.

4. Corley DA, Jensen CD, Marks AR, Zhao WK, Lee JK, Doubeni CA, et al. Adenoma detection rate and risk of colorectal cancer and death. N Engl J Med. 2014;370:1298-306

5. Shen Z, Zhu C, Quan Y, Yuan W, Wu S, Yang Z, et al. Update on intestinal microbiota in Crohn's disease 2017: Mechanisms, clinical application, adverse reactions, and outlook. J Gastroenterol Hepatol. 2017;32:1804-12.

6. Gagniere J, Raisch J, Veziant J, Barnich N, Bonnet R, Buc E, et al. Gut microbiota imbalance and colorectal cancer. World J Gastroenterol. 2016;22:501-18.

7. Backhed F, Ley RE, Sonnenburg JL, Peterson DA, Gordon JI. Host-bacterial mutualism in the human intestine. Science. 2005;307:1915-20.

8. Putze J, Hennequin C, Nougayrede JP, Zhang W, Homburg S, Karch H, et al. Genetic structure and distribution of the colibactin genomic island among members of the family Enterobacteriaceae. Infect Immun. 2009;77:4696-703.

9. Verneuil N, Rince A, Sanguinetti M, Posteraro B, Fadda G, Auffray Y, et al. Contribution of a PerR-like regulator to the oxidative-stress response and virulence of Enterococcus faecalis. Microbiology. 2005;151(Pt 12):3997-4004.

10. Klaunig JE, Kamendulis LM, Hocevar BA. Oxidative stress and oxidative damage in carcinogenesis. Toxicol Pathol. 2010;38:96-109.

11. Fiaschi T, Chiarugi P. Oxidative stress, tumor microenvironment, and metabolic reprogramming: a diabolic liaison. Gastrointest Tumors. 2012;2012:762825.

12. Strickertsson JA, Desler C, Martin-Bertelsen T, Machado AM, Wadstrom T, Winther O, et al. Enterococcus faecalis infection causes inflammation, intracellular oxphos-independent ROS production, and DNA damage in human gastric cancer cells. PloS One. 2013;8:e63147.

13. Yu YN, Fang JY. Gut Microbiota and Colorectal Cancer. Gastrointest Tumors. 2015;2:26-32.
14. Louis P, Hold GL, Flint HJ. The gut microbiota, bacterial metabolites and colorectal cancer. Nat Rev Microbiol. 2014;12:661.

15. de Almeida CV, Taddei A, Amedei A. The controversial role of Enterococcus faecalis in colorectal cancer. Therap Adv Gastroenterol. 2018;11:1756284818783606.

16. Littman AJ, White E, Jackson LA, Thornquist MD, Gaydos CA, Goodman $\mathrm{GE}$, et al. Chlamydia pneumoniae infection and risk of lung cancer. Biomarkers. 2004; 13:1624-30.

17. Koyi H, BrandÉn E, Gnarpe J, Gnarpe H, Steen B. An association between chronic infection with Chlamydia pneumoniae and lung cancer. A prospective 2-year study note. Apmis. 2001;109:572-80.

18. Mager D. Bacteria and cancer: cause, coincidence or cure? A review. J Transl Med. 2006;4:14.

19. Mannick EE, Bravo LE, Zarama G, Realpe JL, Zhang X-J, Ruiz B, et al. Inducible nitric oxide synthase, nitrotyrosine, and apoptosis in Helicobacter pylori gastritis: effect of antibiotics and antioxidants. Cancer Res. 1996;56:3238-43.

20. Baik S-C, Youn H-S, Chung M-H, Lee W-K, Cho M-J, Ko G-H, et al. Increased oxidative DNA damage in Helicobacter pylori-infected human gastric mucosa. Cancer Res. 1996;56:1279-82.

21. Yang Y, Wang X, Huycke T, Moore DR, Lightfoot SA, Huycke MM. Colon Macrophages Polarized by Commensal Bacteria Cause Colitis and Cancer through the Bystander Effect. Trans Oncol. 2013;6:596-606.

22. Hu B, Elinav E, Huber S, Strowig T, Hao L, Hafemann A, et al. Microbiota-induced activation of epithelial IL-6 signaling links inflammasome-driven inflammation with transmissible cancer. Proc Natl Acad Sci U S A. 2013;110:9862-7.

23. Deol PK, Khare P, Bishnoi M, Kondepudi KK, Kaur IP. Coadministration of ginger extract-Lactobacillus acidophilus (cobiotic) reduces gut inflammation and oxidative stress via downregulation of COX-2, i-NOS, and c-Myc. Phytother Res. 2018;32:1950-6

24. Huycke MM, Abrams V, Moore DR. Enterococcus faecalis produces extracellular superoxide and hydrogen peroxide that damages colonic epithelial cell DNA. Carcinogenesis. 2002;23:529-36.

25. Pillar CM, Gilmore MS. Enterococcal virulence--pathogenicity island of E. Faecalis. Front Biosci. 2004;9:2335-46.

26. Zinatizadeh N, Khalili F, Fallah P, Farid M, Geravand M, Yaslianifard S. Potential Preventive Effect of Lactobacillus Acidophilus and Lactobacillus Plantarum in Patients with Polyps or Colorectal Cancer. Arq Gastroenterol. 2018;55:407-11. 